\title{
MONITORING OF THE EDUCATIONAL ADULT CENTER: SEEKING WAYS FOR IMPROVING THE ACTIVITY WITH PEOPLE OF "THE THIRD AGE"
}

Erkin Isimbaev', Inna Dubrovina, Marat Konkashev, Rose Mukanova

Orleu Institute for Advanced Training Teachers Akmola Region, Kokshetau, Kazakhstan

\section{ABSTRACT}

The authors discuss the experience of the educational adult center in the context of the idea - "education throughout the life". In the frame of the last three years the Centre organized the monitoring and analytical work to create a system of education and finding ways to improve the efficiency of working with people of "the third age". The article presents the facts and analytical conclusions on the results of the monitoring.

\section{JEL CLASSIFICATION \& KEYWORDS}

H55 PEOPLE OF THE "THIRD AGE" THE ELDERLY ADULTEDUCATION TRAINING LIFELONG CONTINUOUS ADULT EDUCATION ADULT EDUCATION CENTER

\section{INTRODUCTION}

The organizing activities in additional education system, a branch of JSC "NTSPK" leading and "Training Institute of teachers on Akmola region" is in constant search of new meanings to apply their creative and professional efforts. In order to implement the State Program of Education Development of the Republic of Kazakhstan for 2011-2020, since 2012, the Institute is working towards the implementation of "learning throughout the life" by offering educational services to the society for people of "the third age" (Yunatskevich, 2009). Having accumulated the ideas and experience in the implementation of adult education in the country and abroad (Dotol, 2010), on the basis of the branch team was opened the Center for Adult Education (hereinafter Center, or CAE).

Originally conceived as a training of older people the knowledge and skills in the various fields of education (Elizarova, 2005), the idea of adult education developed into a selfless branch employees, aimed at uniting people of retirement age of Kokshetau city, congenial, requiring communication, cultural leisure among like-minded people.

This is the fourth year the staff of the branch carries out the activity of the Center for Adult Education under the program of continuing education of people of "the third age" (Olex, 2006). Today the Center is the only project in the region in the educational environment aimed at spiritual and intellectual development of adults, their further socialization, promoting physical and psychological well.

The process of learning the older generation, like any activity, which has a prolonged character and focused on achieving results, needs determining the quality of the work, development trends and finding ways to improve. In this regard, it developed the system of monitoring of activities aimed at identifying the current situation and the interim results, the quality of operations, as well as the search for optimal ways to improve work with people of "the third age" (Orleu, 2013, 119 p.).

\section{' idt12@mail.ru}

www.journals.cz

\section{Main part}

For four years, from 2013 to 2016 , CAE is gradually increasing its educational potential and extends the coverage of the educational activities of the elderly, we respectfully call "active people".

Starting with a small, the branch staff in the face of enthusiastic teachers in three of the past year gained some experience in the organization of this activity.

From the very beginning it was important for us not only to attract the largest number of listeners for the Center, but also to create for them a comfortable environment for interaction and communication, development and training. To this end, teachers call centers carry out appropriate work to attract people interested in learning, development of educational programs.

According to the Center for Monitoring the number of students in three years increased by 5 times (Figure 1). Since the opening has been formed, one group of students with a total of 8 people. After three years of work, students are organized into a full band with different educational and personal needs, the active position in the training. It is an indicator of the effectiveness of the work and its attractiveness to the category of people of "the third age".

Figure 1: Number of students of Adult Education Center in the period from 2013 to 2016

Adult Education Center listeners in period from 2013 to 2016

40

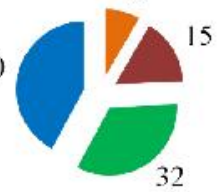

2013 год 2014 год $2015 \mathrm{rog}$ $2016 \mathrm{rog}$

Source: Compiled by the authors

The listeners of the Center for Adult Education for four years are the veterans of pedagogics and labor veterans/retirees from other sectors of the economy. It is noteworthy that every second pensioner comes to the Center learns out about the Center from the neighbors, many students were brought to the Center by their friends, acquaintances, and even their own adult children are interested in the cultural leisure of their elderly parents.

Among the students of the Centre is growing the number of pensioners even are not related to education. This retired health care, social services, culture and the arts, industrial and agricultural employees (Figure 2). For us, this means that a joint learning environment and communication created by the teachers of the Institute, became in a great interest not only for teachers at work, but also people who work in the other areas. 


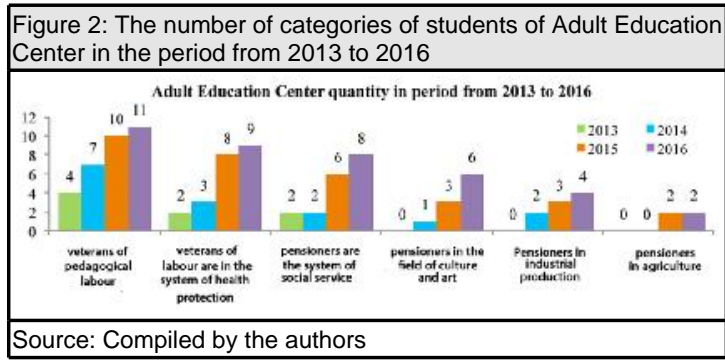

Such volatile in their professional interest of the audience needs to be saturated with the training program. The idea was for the teachers of the Center impetus for the development of training programs to enable students to meet their educational and cultural needs. Gradually over three years teachers increased their educational potential of adult education center (Figure 3 ).

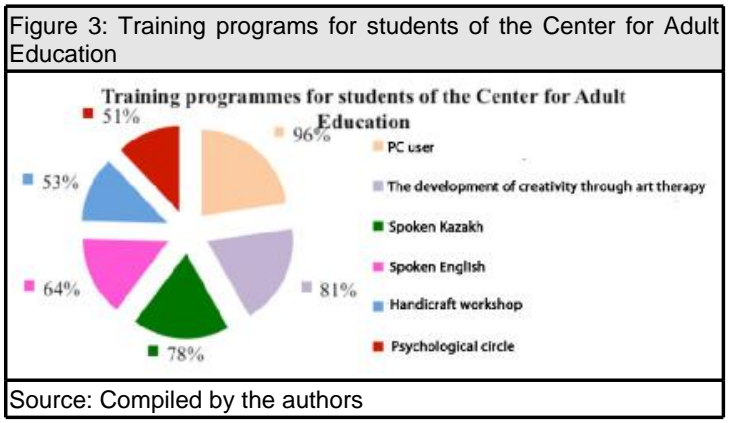

Complex classes offered by our active adults in four years has undergone changes and has grown from the two programs in 2013 to six in 2016. Thinking about what to offer the listeners for the replenishment of baggage of their knowledge, teachers CAE training programs started with computer skills and language skills (Kazakh, English).

To date, the Center for teachers working with students in six areas, the subject of which has expanded considerably. Today, our "active people" learn Kazakh and English languages, master the skills of working with computers and the Internet, to develop their creative abilities, engaged in psychological circle and master the skills of needlework (Table 1). All programs are in demand.

Thus, for the three years of the Centre of Adult Education there have been major changes in the organization of its activities: increase the number of listeners increased the number of categories of participants in training, increased the number of educational programs offered to students. And, perhaps most importantly - formalized cooperation communication of our esteemed "active adult" has grown into an informal, friendly, full stakeholder participation.

To create an effective system of training the work call centers throughout the period was accompanied by a monitoring service. The ongoing monitoring and analytical work consists of two parts:

1. Preliminary diagnosis (questioning) students' needs, motives and goals of their participation in educational activities. The survey questions are worded in such a way as to obtain comprehensive information about the educational needs of the students of the Centre in order to take it into account when building a program of training, the choice of content and structural components. For teachers it was also important to help students identify with the demand of the productive forms of organizing training sessions and ways to maintain interaction with the adult education center in the future.

Analysis of data for monitoring the educational needs of students of the Centre of Adult Education of the input materials survey led to the following conclusions. For students of the Center for overdue completion of their existing life and professional experience, knowledge and skills to solve problems in life in accordance with the increased demands of life in a rapidly changing world The main reasons behind people's "third generation" of learning, are, first of all, the problems of life or circumstances for which the need for new knowledge. Students expressed their inner need for communication, interaction and learning in an environment comfortable for themselves, which provides them with the center (Figure 4).

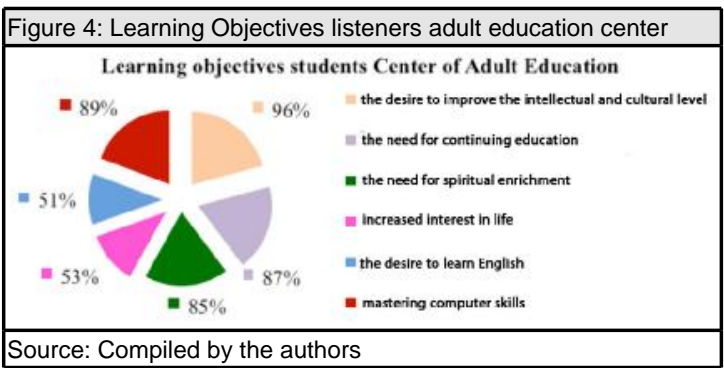

In the evaluation of forms of organization of the most productive activities to improve the intellectual and cultural level, according to the CAE students are practice oriented forms that allow themselves to be active listeners (Figure 5).

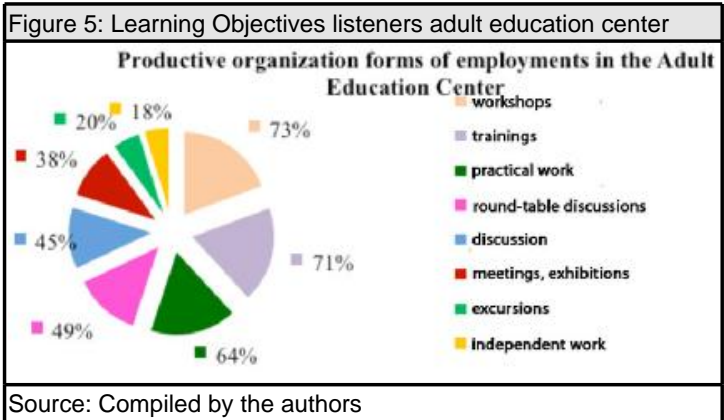

The Center's students showed the interest for diverse topics and educational programs and are ready to raise the level of theoretical knowledge and practical skills. All $100 \%$ prefer full-time training, but the students have expressed interest in networking as a new form of communication for themselves over the Internet.

This information allowed the teaching staff of the Centre to take into account the interests of focus, motivation training and other preferences of listeners in the planning work.

2. Study of personal change among the audience in 3 years after the start of training, by the end of 2015, on the basis of self-assessment. In order to determine the degree of satisfaction with the training, achieving the objectives of the courses, the indicators characterizing personality changes, as part of an integrated monitoring at the final stage of training annually feedback from students in the form of exit surveys. The above mentioned parameters and help to assess the quality of the educational process. 
Achieving the goal of course, personality changes by the end of the third year of study students are evaluated Center for three years rather positive. All $100 \%$ of students feel a sense of satisfaction, of which a large part - $72 \%$ experience the creative impulse (Figure 6).

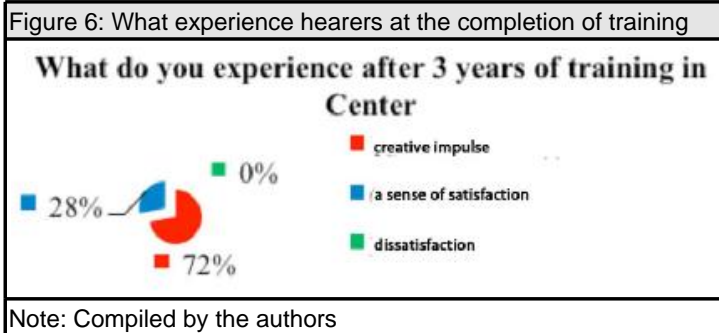

By the end of the third year the students from $96 \%$ to $100 \%$ of students say raising the acquired skills and knowledge (Figure 7).

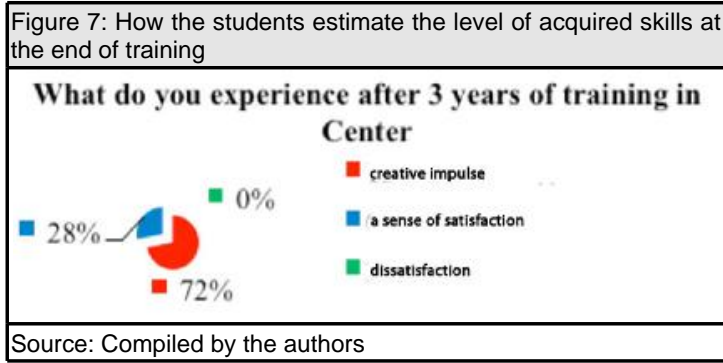

Within three years of steady $100 \%$ the students estimate the level of teachers is high enough, the increasing every year evaluation of teachers at a high level if in 2013 appreciated $63 \%$, in 2015 already $84 \%$ of students (Figure 8).

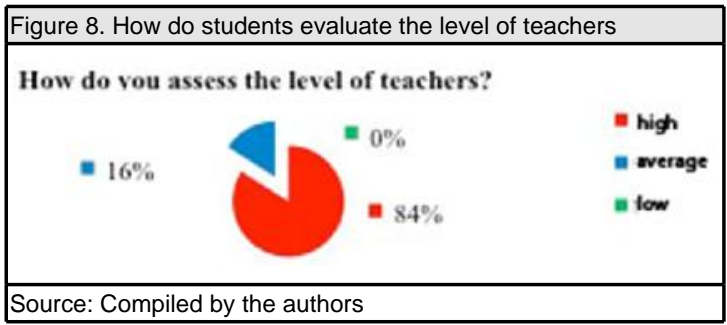

Thus, self-esteemation among the audience personality changes as a result of the CAE output survey shows appreciation due to the teachers' activity, satisfaction with the quality of educational programs, the results of their own work, and to raise the level of existing and acquired skills. Moreover, there is a positive trend as the assessment of their own achievements in teaching and assessment of teachers of the Centre.

Holistic analysis of monitoring data led to the conclusion that the training at the Centre provides the students with opportunities to find new life goals for themselves and future self. Communication with like-minded people helps older people to solve the problem of rehabilitation in society, successfully pass the adaptation period in retirement, helps to activate vitality. The students of the Center are not only acquired new friends and broaden their interests, but also gain new knowledge and skills in the areas of knowledge that were previously unavailable to them. Thus, the students have many positive effects on learning and communicating with other people in the center of adult education.

\section{CONCLUSION}

Summarizing the Center for Adult Education's activity, the monitoring data, it is safe to make the following conclusions. The Centre is a great project in the field of adult education and not only proves its relevance, efficiency and effectiveness, but also has a beneficial impact on the lives of older people, the students of the Centre. Summing up the work at this stage is important for understanding the development prospects, finding ways to improve performance (Anoshkina, 2001). To do this, you must define the tasks for the future - it will be the beginning of the next stage.

The work of the Centre of Adult Education may be recognized as an important link in the process of realization of the goals and objectives of the society by the President of the Republic of Kazakhstan Nursultan Nazarbayev, - assistance in getting people "education throughout life", the search for new meanings of life, extending the age of vitality and longevity.

\section{REFERENCES}

Anoshkina, V.L. (2001). Education. Innovation. Future. (methodological and socio-cultural issues). Rostov - on - Don.

Dotol, I.V. (2010). The urgency problem of adult education in Russia - http://cyberleninka.ru/article/n/aktualnost-problemy-obrazovaniyavzroslogo-naseleniya-rossii

Elizarova, E.N. (2005). Adult Education in Russia: Problems and priorities - http://cyberleninka.ru/article/n/obrazovanie-vzroslyh-vrossii-problemy-i-prioritety-razvitiya

Orleu(2013). Monitoring technology as a means of tracking and quality control training teachers - Almaty, JSC "National Centre of Excellence" Orleu, p. 119

Olex, O.A. (2006). About the quality policy priorities of adult education in the Republic of Belarus http://cyberleninka.ru/article/n/ obrazovanie-vzroslyh-v-rossii-problemy-i- prioritety-razvitiya

Yunatskevich, P.I. (2009). The theory of adult education: formation, problems, challenges - http://vce-znau.ru/pravo 